\title{
THE MAIN DIRECTIONS OF FORMATION OF SOCIO-CULTURAL COMPETENCE IN STUDENTS
}

\author{
Zarifaxon Solijon qizi Jakbarova \\ Independent researcher, Fergana State University, Uzbekistan
}

\section{ABSTRACT}

The article reveals the scientific significance of the formation of socio-cultural competence in students. The main directions of formation of socio-cultural competence in students were analyzed. Also, pedagogical opportunities for the formation of socio-cultural competence are scientifically based.

KEYWORDS:- Culture, social culture, competency, pedagogical process, professional activity, educational system, pedagogical activity.

\section{INTRODUCTION}

In today's world, where education is valued as the most unique capital in the world, "at all stages of education, it is important to create opportunities for all people to receive quality education throughout their lives through the introduction of mechanisms to improve the effectiveness and methods of evaluating learning outcomes" [2,56]. Association for Educational Communications and Technology AECT (USA), Belfield Pedagogical University (Germany), Center for increasing pedagogical qualification on the basis of Manchesters University (Great) Britain); Chunang University (South Korea), Miyagi Pedagogical University (Japan), Academy of Education (Russia), Swiss Federal Institute of Technology (Switzerland), University of Bridgeport (Chicago), University of Warwick (London) and Edith Cowan University
(Amsterdam) a number of practical results have been achieved in prestigious higher education institutions and centers. This is important in the organization of pedagogical processes aimed at the formation of socio-cultural and professional skills and personal qualities of students.

Strengthening the material and technical base of higher education institutions in the country, improving the teaching and methodological support, increasing the initiative of teachers to implement advanced educational technologies and teaching methods as a result of reforms in the field of training, Opportunities to increase the social culture of students, the introduction of interactive teaching methods are expanding. There is also a need to improve the content of professional and pedagogical activities of teachers and students of higher education institutions on the basis of advanced foreign experience and socio-cultural ties. The Action 
CURRENT RESEARCH JOURNAL OF PEDAGOGICS 2(9): 183-186,

September 2021 DOI: https://doi.org/10.37547/pedagogics-crjp-02-09-38

ISSN 2767-3278

(C)2021 Master Journals

Crossref do: 81 Google

Accepted 25 $5^{\text {th }}$ September, 2021 \& Published 30th September, 2021

Strategy for the further development of the Republic of Uzbekistan identifies priorities such as the adaptation of the quality of education in higher education institutions to the current and future needs of the individual, state and society and the study of socio-cultural development [1]. analysis of socio-cultural, professional and pedagogical conditions and practice of teaching students, organization of pedagogical conditions for the formation of socio-cultural competence of teachers and students, the form, methods and means of formation of socio-cultural competence It is important to increase the efficiency of the application. B.Adizov, B.Rakhimov on the development of social activity in students, the content of social activity in youth consists of components of socio-national consciousness, activism, national pride, pedagogical bases of development of spiritual and social activity of students on the example of youth organizations, pedagogical issues of competence J.Tulenov TAEgamberdiyeva, K.Quranbaev in the research work. Based on the above, it can be said that the issue of formation of socio-cultural competence in students has not been sufficiently studied.

The development of socio-cultural competence has a special place in the modern world, which prevents the escalation of interethnic relations. Socio-cultural competence includes readiness and ability to live and communicate in a modern multicultural world [4,36]. Socio-cultural competence is a great opportunity to teach students tolerance, respect for other people, peace and friendship with all peoples. The formation of socio-cultural competence of students plays an important role in educating the patriots of their country. If a student knows, appreciates and respects the culture, customs, traditions, language of other countries and peoples, he can proudly present the culture and customs of his own people or the region in which he lives, no hostility., there is no room for competition or dominance. The most important aspect of socio-cultural competence also serves to achieve interethnic harmony, as well as to ensure peace and unity of peoples. The formation and development of components of sociocultural competence allows the student to predict the socio-cultural characteristics of the people with whom he communicates, the sociocultural interventions that may occur in the context of intercultural communication and ways to overcome them. It lays the foundation for the independent study of other countries, peoples, cultural communities; mastering the methods of expressing native culture in a foreign environment; promotes socio-cultural selfeducation in other, previously unexplored areas of direct and mediated communication.

The concepts of culture, social culture and sociocultural competence complement each other. The main areas of culture, socioculture and sociocultural competence and the object of its research can be defined as follows $[3,46]$ :

- The role of language as a means of communication in society;

- knowledge that is the wealth and criterion of society;

- human customs, traditions, folklore, art and literature, religions;

- social relations and methods of communication between them, social organizations;

- rituals, pineapples, family, property that are part of daily life;

- socio-economic, political demographic, ethnic processes taking place in society, etc.

Socio-cultural competence is an integral part of communicative competence, a set of knowledge about the culture, language, national and cultural features of social behavior and attitudes accepted by society, the application of this 
CURRENT RESEARCH JOURNAL OF PEDAGOGICS 2(9): 183-186,

September 2021 DOI: https://doi.org/10.37547/pedagogics-crjp-02-09-38

ISSN 2767-3278

(C)2021 Master Journals

Crossref do: 81 Google

Accepted 25 $5^{\text {th }}$ September, 2021 \& Published 30th September, 2021

knowledge in communication practice and certain customs, the ability to follow rules of conduct, rules of behavior, and ster

Components of socio-cultural competence:

- -socio-cultural knowledge (knowledge of spiritual values, customs and cultural traditions, specific features of the national mentality);

- -communication experience (choice of social culture style, correct interpretation of foreign cultural events);

- emotional response to culture (including the ability to resolve conflicts that arise during communication);

- know how to apply the rules of ethics, the correct use of social etiquette.

- In our opinion, the formation of sociocultural competence results in:

- expanding the scope of knowledge about spiritual values, customs and cultural traditions, the peculiarities of the national mentality;

- extensive knowledge of language, science and culture, historical and modern cultures, public figures, the role of countries in the world community and the world cultural space;

- to have the skills and abilities related to the adequate application of the rules of conduct to the social ethics accepted by society;

- to have knowledge about the nationalcultural features of social behavior and attitudes accepted by the society.

The creative ability and socio-cultural competence of the future teacher is reflected in the teaching process.eotypes.

This allows teachers to build trusting relationships with students. In this case, the cooperation has the character of imitation (imitation, simulation) and a situation of discussion arises between students, but the tasks set before them are not solved. In order to achieve the goal set by the teacher and to achieve the quality of teaching, it is important that the music education teacher forms a low level of socio-cultural competence. It is advisable to use the following conditions for the development of creativity and socio-cultural competence in the teacher:

- Informing students about national values,

- to tell an interesting life story on a topic,

- open and friendly conversation with students,

- fair assessment of students' knowledge,

- encourage creative achievement,

- show personal sample,

- have interesting conversations with celebrities for students,

the search for a solution to a single problem can be cited.

The student requires the teacher to work on a little to shape the sociocultural competence of the youth. Therefore, any educator should strive to research in the field of education, to achieve positive results, to create his own style.

Based on the above considerations, a technology has been developed to ensure the success of the process of forming socio-cultural competence in students. It organized a basic three-tier system (motivational, lessening, less conscious).

The content of the motivational stage: the formation of socio-cultural perceptions, professional orientation, aspiration to pedagogical activity. Forms, methods, tools: debates, castings, briefings, meetings, seminars, small groups, presentations, etc.

The content of the stage of reduction of performance requirements: socio-cultural and 
CURRENT RESEARCH JOURNAL OF PEDAGOGICS 2(9): 183-186,

September 2021 DOI: https://doi.org/10.37547/pedagogics-crjp-02-09-38

ISSN 2767-3278

(C)2021 Master Journals

Crossref dof 81 Google

Accepted 25th September, 2021 \& Published 30 ${ }^{\text {th }}$ September, 2021

professional competencies, performance requirements, reduction of values. Forms, methods, tools: informative lectures, discussions, seminars, case studies, role-playing games, webinars, forums, etc.

The content of the stage of low awareness: finding a small place in the group and professional environment, active involvement in working conditions, socio-cultural and professional formation. Form, method, tools: SWOT and TOWS-analysis, essays, trainings, graphic organizers and others.

It is known that the process of formation of socio-cultural competence in students is a complex and individual process. At the same time, it is expedient to study the individuality of the student's personality, learning conditions, environment and the system of interpersonal relationships in interdependence. In addition, the effective process of adaptation leads to the formation of axiological approach to the professional activity of future teachers, their professional development. This has little effect on the efficiency, effectiveness and longevity of the professional.

The degree to which a society is developed is determined, first of all, by the potential of the youth that determines its future. In fact, while we constantly protect young people from spiritual threats, we should try to instill in them immunity to spiritual threats as well.

In short, socio-cultural competence in students affects not only the development of social culture, but also professional development, which in turn serves to increase the potential of students. on the strategy of further development of the Republic of Uzbekistan for 2017-2021. 2017, No. 6, Article 70. Source: www.gov.uz.

2. Incheon Declaration / Education 2030: Towards inclusive and equitable quality education and lifelong learning for all (Word Education Forum, 19-22 May 2015, Incheon, Republic of Korea). 56-c

3. Flier A. Ya. Kulturologiya dlya kulturologov: uchebnoe posobie dlya magistrantov i aspirantov, doktorantov i soiskateley, a takje prepodavateley kulturologii / M .: Akadem.prospekt.2002 - 46 s.

4. Vorobev, G.A. Development of sotsiokulturnoy kompetentsii budushchix uchiteley inostrannogo yazyka (poisk effektivnyx putey) / G.A. Vorobev // Foreign languages in school. - 2003. - №2. - S. 30-36.

5. Ismatullayeva, N. R. (2021). On the Introduction of E-Learning Portfolio in the Educational Process. Current Research Journal of Pedagogics (2767-3278), 2(09), 35-37.

\section{REFERENCES}

1. Decree of the President of the Republic of Uzbekistan No. PF-4947 of February 7, 2017 